\title{
Risk factors for low urinary citrate in calcium nephrolithiasis: low vegetable fibre intake and low urine volume to be added to the list
}

\author{
B. Hess ${ }^{1}$, R. Michel ${ }^{1}$, R. Takkinen ${ }^{1}$, D. Ackermann ${ }^{2}$, Ph. Jaeger ${ }^{1}$ \\ ${ }^{1}$ Policlinic of Medicine and ${ }^{2}$ Department of Urology, University Hospital, Berne, Switzerland
}

\begin{abstract}
Risk factors for low urinary citrate excretion were assessed in 34 consecutive male recurrent idiopathic calcium stone formers (RCSF) who collected two 24-h urines while on free-choice diet. Overt hypocitraturia (hypo-cit) was defined as $\mathrm{U}_{\text {Cit }} \times \mathrm{V}<1.70 \mathrm{mmol} /$ day, and 'low' citraturia (lowcit) as $\mathrm{U}_{\mathrm{Ctt}} \times \mathrm{V}$ between 1.70 and $2.11 \mathrm{mmol} /$ day. Twenty-three RCSF had normocitraturia (normo-cit), six low-cit and five hypo-cit. $\mathrm{U}_{\mathrm{Cit}} \times \mathrm{V}$ positively correlated with urine volume (VOLUME, $r=0.44$, $P=0.009$ ), vegetable fibre intake (fibers, $r=0.46$, $P=0.009$ ) and GI-alkali absorption (alkali, $r=0.47$, $P=0.006$ ), and volume, fibres and alkali tended to be lower among RCSF with low-/hypo-cit. A 3-day $\mathrm{NH}_{4} \mathrm{Cl}$ loading test $(0.95 \mathrm{mEq} / \mathrm{kg}$ BW daily in 3 doses $)$ was performed in RCSF as well as in 14 age-matched healthy male controls (C). On a plot of urine $\mathrm{pH}$ versus serum bicarbonate, 10 of 11 RCSF with low/hypo-cit, but only six of 23 with normo-cit $(P=$ 0.0004 ) fell off the normal range, indicating incomplete RTA. Two or more risk factors simultaneously occurred in only four of $23 \mathrm{RCSF}$ with normo-cit, but in eight of 11 with low-/hypo-cit $(P=0.002)$. In conclusion, incomplete RTA is the most prevalent risk factor for low-/hypo-cit in RCSF, and decreases in vegetable fibres and urine volume emerge as two new risk factors for low urinary CIT.
\end{abstract}

Key words: calcium nephrolithiasis; citrate; gastrointestinal alkali absorption; renal tubular acidosis; urine volume; vegetable fibres

\section{Introduction}

Low urinary citrate excretion is an accepted pathogenic factor for calcium renal stone formation [1,2]. Variations of systemic acid-base status have been shown for a long time to influence urinary citrate excretion [3]: for instance, metabolic alkalosis increases urinary citrate [4], whereas ammonium-chloride-

Correspondence and offprint requests to: B. Hess MD, Policlinic of Medicine, University Hospital, CH-3010 Berne, Switzerland. induced acidosis lowers its excretion by $20-50 \%$ within a few hours [5]. Owing to the fact that cytosolic acidification activates citrate uptake by the proximal tubular cell [3], intracellular rather than systemic acidosis has been postulated as the denominator common to most patients with 'idiopathic' hypocitraturia [6].

Indeed, overt metabolic acidosis is usually absent in recurrent calcium renal stone formers with 'idiopathic' hypocitraturia. With the help of the classic ammonium chloride loading test, however, we [6] and others [7] have provided evidence for incomplete renal tubular acidosis (RTA) in a substantial fraction of patients with 'idiopathic' hypocitraturia. Such a reduced capability of renal acid excretion may favour intracellular acidosis and thus cause hypocitraturia in these patients.

Dietary factors also modulate the urinary excretion rate of citrate. Excess animal protein intake with the acid load that it conveys lowers urinary citrate $[1,8]$, whereas dietary protein restriction does the opposite [9]. Urinary citrate positively correlates with net gastrointestinal absorption of alkali, which seems to be reduced in many idiopathic calcium stone formers [1]. Potassium depletion also triggers hypocitraturia $[5,10]$ : it appears to do so via stimulation of the sodiumcitrate cotransport system at the brush-border level of the proximal tubular cell, and intracellular acidosis, again, might provide the key signal [11]. Additionally, sodium chloride loading depresses urinary citrate; this effect may, again, be governed by intracellular acidosis, due to sodium-induced volume expansion with subsequent rise in urinary bicarbonate excretion [1].

Finally, primary intestinal malabsorption of citrate has been postulated to account for 'idiopathic' hypocitraturia in some patients with idiopathic calcium nephrolithiasis [1].

Given a population of patients with idiopathic calcium nephrolithiasis studied on their free-choice diet [12], the present study aimed to address the following issues: (1) what is the prevalence of 'idiopathic' hypocitraturia?; (2) among patients who turn out to have low urinary citrate, how often does the disorder have a metabolic origin, and how often a nutritional one?; (3) are there other mechanisms to account for low urinary citrate than those alluded to above? 


\section{Subjects and methods}

From the patients routinely seen for metabolic work-up at our renal stone clinic, 34 consecutive male recurrent idiopathic calcium stone formers (RCSF) meeting the following criteria were studied: (1) passage or removal of at least two calcium-containing stones, defined either by stone analysis (X-ray diffraction) or disappearance of opaque material on conventional radiographs or excretory urograms; (2) no established cause of calcium stone formation such as primary hyperparathyroidism, medullary sponge kidney, overt distal renal tubular acidosis, sarcoidosis, excessive vitamin D intake, and hypercalciuria due to hypercalcaemia of malignancy or immobilization; (3) absence of obvious causes of hypocitraturia such as malabsorption with steatorrhoea [13], hypokalaemia (serum $\mathrm{K}<3.5 \mathrm{mmol} / \mathrm{l}$ ) due to acetazolamide or thiazide treatment, or urinary tract infection [14]; and (4) $\mathrm{C}_{\text {crea }}>70 \mathrm{ml} / \mathrm{min} / 1.73 \mathrm{~m}^{2}$.

Adl RCSF were referred after ESWL or endourolegical treatment of their stone disease, and they were asked to keep unchanged the free-choice diet they used to have before stone treatment. They were never studied until at least 2 months had elapsed after urological intervention. Other medications known to interfere with calcium and citrate metabolism were discontinued at least 2 weeks prior to evaluation.

The normal values for 24-h urinary excretion rates currently used in our stone clinic are based on 107 healthy male volunteers living in the area of Berne, Switzerland, while on a free-choice diet. Upper normal levels (95th percentile) are $9.00 \mathrm{mmol} / \mathrm{d}$ for calcium, $440 \mu \mathrm{mol} / \mathrm{day}$ for oxalate, and $5.00 \mathrm{mmol} /$ day for uric acid; the lower normal level of $\mathrm{U}_{\text {Cit }} \times \mathrm{V}$ (5th percentile) is $1.70 \mathrm{mmol} /$ day $(320 \mathrm{mg} / \mathrm{d})$. In an early report by Hodgkinson [15], hypocitraturia in men had been defined as $\mathrm{U}_{\mathrm{Cit}} \times \mathrm{V}<2.12 \mathrm{mmol} /$ day $(<400 \mathrm{mg} / \mathrm{day})$; accordingly we subclassified our RCSF into those with overt hypocitraturia (hypo-cit), i.e. $U_{\mathrm{Cit}} \times \mathrm{V}<1.70 \mathrm{mmol} /$ day ( $<320 \mathrm{mg} /$ day), and those with 'low citraturia' (low-cit), i.e. $\mathrm{U}_{\mathrm{Cit}} \times \mathrm{V}$ between 1.70 and $2.11 \mathrm{mmol} / \mathrm{d}(320-399 \mathrm{mg} /$ day). Since the risk of calcium stone formation has been demonstrated to increase exponentially with decreasing 24-h urine volumes below $1200 \mathrm{ml}$ [16], 'low volume' was defined as $<1200 \mathrm{ml} /$ day. All RCSF collected two 24-h urine specimens according to our standard protocol [12]; 24-h urine values are expressed as the means of both collections.

Twenty-four-hour urines were collected in 3-litre plastic bottles containing $10 \mathrm{~g}$ of boric acid as preservative agent. Specimens were analysed for creatinine (Crea), calcium (Ca), phosphate $(\mathrm{P})$, sodium $(\mathrm{Na})$, potassium $(\mathrm{K})$, chloride $(\mathrm{Cl})$, magnesium ( $\mathrm{Mg}$ ), uric acid (UA) and urea by autoanalyser techniques. Citrate (Cit) was measured using the citrate lyase method [17]. Oxalate (Ox) was measured after enzymatic oxidation of oxalate by oxalate oxidase [18] as previously described [12]. Urinary sulphate (Sulph) was measured by an HPLC system utilizing an anion column to separate sulphate from other urinary anions, where sulphate is detected by conductivity change as eluent flows through a conductivity cell [19].

Urinary excretion rates of urea, UA and Sulph were taken as markers of animal protein consumption, and $U_{\mathrm{Na}} \times \mathrm{V}$ as a measure of sodium intake. Since fibre-rich foods such as vegetables, grain products, and fruits are sources of alkali [20], alkali consumption was estimated from the daily ingestion of vegetable fibres, subsequently referred to as 'dietary fibres'. The latter ones were assessed from the patients' diet protocols filled out during collections of 24-h urines, by means of food composition and nutrition tables [20], i.e. two 24-h diet protocols were retrospectively analysed from each patient; direct measurements of food compositions were not performed. Since dietary fibre contributes $15-25 \mathrm{~g}$ to the average US diet [21], ingestion of less than $15 \mathrm{~g}$ /day was defined as low dietary fibre intake, indicating lower alkali consumption. Net gastrointestinal absorption of alkali (expressed in $\mathrm{mEq} / 24 \mathrm{~h}$ ), subsequently referred to as 'GI-alkali', was derived from 24-h urine excretions of noncombustible cations and anions according to the formula

$(\mathrm{Na}+\mathrm{K}+\mathrm{Ca}+\mathrm{Mg})-(\mathrm{Cl}+1.8 \times \mathrm{P})[1,22]$,

where electrolyte excretions are in $\mathrm{mEq} /$ day except for $\mathbf{P}$ which is in mmol/day with an average valence of $1.8[1,22]$. Low GI-alkali was defined as $<15 \mathrm{mEq}$ /day, since the lower normal limit (5th percentile) among our male healthy volunteers was $15 \mathrm{mEq} /$ day.

An ammonium chloride loading study was performed in all RCSF and additionally in 14 of our 107 healthy male volunteers, aged $44.2 \pm 2.6$ years (range 28-62) and with normokalaemia (fasting serum $\mathrm{K}$ concentration between 3.5 and $4.1 \mathrm{mmol} / \mathrm{l}$ ). It consisted of sampling venous blood and 2-h urine after $12 \mathrm{~h}$ without eating and $8 \mathrm{~h}$ without drinking (only tap water allowed after the last meal) on day 0 (indicated as ${ }_{0}$ ). From then on, ammonium chloride $\left(\mathrm{NH}_{4} \mathrm{Cl}\right)$ was added to the free-choice diet of each subject for 3 days and given in three divided doses $20 \mathrm{~min}$ before each meal (total $0.05 \mathrm{~g} / \mathrm{kg} / \mathrm{day}$, or $0.95 \mathrm{mEq} / \mathrm{kg} / \mathrm{day}$ ). On day 3 , sampling of fasting venous blood and 2 -h urine was repeated (indicated as ${ }_{3}$ ). For the nomogram of fasting venous bicarbonate concentration versus urine $\mathrm{pH}$ after acid loading only (Figure 2), nine additional male healthy volunteers were included from a previous study with $\mathrm{NH}_{4} \mathrm{Cl}$ loading [6].

Plasma concentrations of Crea, total $\mathrm{Ca}, \mathrm{P}, \mathrm{Mg}, \mathrm{Na}, \mathrm{K}$, $\mathrm{Cl}$, UA, and total protein were measured by autoanalyser techniques. Serum anion gap, an indirect index for unmeasured anions, was defined as $\left[\mathrm{Na}^{+}\right]-\left[\mathrm{Cl}^{-}+\mathrm{HCO}_{3}^{-}\right]$; normal values were $8-16 \mathrm{mmol} / \mathrm{l}$. In whole blood, ionized calcium $\left(\mathrm{Ca}^{2+}\right)$ was measured by an ion-selective electrode (Ciba-Corning Diagnostics Corp., Medfield, Massachusetts, USA) and bicarbonate by a Ciba-Corning 278 blood gas system (Ciba-Corning Diagnostics Corp.) immediately after sampling without compression. Serum intact parathyroid hormone (PTH) concentration was measured by a radioimmunoassay kit (Nichols Institute, San Juan Capistrano, California, USA); normal values are $10-65 \mathrm{pg} / \mathrm{ml}$. Serum 25 $(\mathrm{OH})$ vitamin $\mathrm{D}$ (normal range $6-40 \mathrm{ng} / \mathrm{ml}$ ) and serum 1,25 $(\mathrm{OH})_{2}$ vitamin $\mathrm{D}_{3}$ (calcitriol, normal range $25-79 \mathrm{pg} / \mathrm{ml}$ ) were measured by radioimmunoassay (Nichols Institute, San Juan Capistrano, California, USA).

In freshly voided 2 -h fasting urines, $\mathrm{pH}$ was measured by a Metrohm 654 pH-Meter (Metrohm, Herisau, Switzerland). The fasting urines were analysed for $\mathrm{Ca}, \mathrm{P}, \mathrm{Na}, \mathrm{K}, \mathrm{Cl}$, urea, and crea by autoanalyser techniques. Hydroxyproline (OHP) was assayed using a kit (Hypronosticon ${ }^{B}$, Organon Teknika, Boxtel, The Netherlands), where OHP is coloured by the Ehrlich's reagent and quantified photometrically after binding to an acid cation exchange resin, hydrolysis $(16 \mathrm{~h})$ and oxidation. Urinary anion gap (AG), an indirect measure of urinary ammonium concentration [23], was calculated as $[\mathrm{Na}]+[\mathrm{K}]-[\mathrm{Cl}]$. All 2-h fasting urine values are presented in relation to urine creatinine concentration $(\mathrm{mmol} / \mathrm{mmol}$ ratio), except renal phosphate threshold (TmP/GFR), which was derived from the nomogram of Walton and Bijvoet [24], and OHP-E ( $\mu \mathrm{mol} / 1 \mathrm{GF})$, which was calculated using the formula $\mathrm{OHP}_{u} / \mathrm{Crea}_{U} \times \mathrm{Crea}_{\mathrm{s}}$.

All values are presented as means \pm SEM. Non-parametric Mann-Whitney U-test for comparisons between and 
Wilcoxon signed-rank test for comparisons within groups were used. Simple and multiple linear regression analysis was performed for correlation studies.

\section{Results}

The 34 male RCSF participating in the study were $42.7 \pm 1.6$ years old (range 23-64, not different from controls). None of them had hypokalaemia ( $<3.5 \mathrm{mmol} / 1$ ), their fasting serum $\mathrm{K}$ concentrations ranging between 3.5 and $4.5 \mathrm{mmol} / \mathrm{l}$. Twenty-three RCSF $(67.6 \%)$ were normocitraturic (normo-cit), whereas $\mathrm{U}_{\mathrm{Cit}} \times \mathrm{V}$ was below $2.12 \mathrm{mmol} / \mathrm{day}$ in $32.4 \%$ (combined low-/hypo-cit), i.e. low-cit $(1.70-2.11 \mathrm{mmol} / \mathrm{day})$ in $\operatorname{six}(17.6 \%)$ and hypo-cit $(<1.70 \mathrm{mmol} / \mathrm{day})$ in five RCSF (14.8\%). Among patients classified as normo-cit, two of 23 had $\mathrm{U}_{\mathrm{Cit}} \times \mathrm{V}<2.12 \mathrm{mmol} / \mathrm{day}$ in one of their two urine collections. Four of six RCSF with low-cit had urinary citrate $<2.12 \mathrm{mmol} /$ day in only one urine collection, whereas four of five RCSF classified as hypo-cit had $\mathrm{U}_{\mathrm{Cit}} \times \mathrm{V}<1.70 \mathrm{mmol} /$ day in both 24 -h urines. Among healthy volunteers, urinary citrate $<2.12 \mathrm{mmol} /$ day occurred in 19 of 107 normal controls (17.8\%), i.e. 12 (11.2\%) had hypo-cit and 7 (6.5\%) low-cit. Twelve RCSF had hypercalciuria (HCSF), and 22 were normocalciuric (NCSF). Dietary protocols from 31 RCSF $(91.2 \%)$ were available to us for further analysis; three of them (in 3 RCSF with normo-cit) were inappropriately filled out.

\section{Twenty-four-hour urine data}

Table 1 summarizes the main parameters derived from 24-h urine collections in RCSF. With the exception of Gl-alkali, which was only $14 \pm 4 \mathrm{mEq} /$ day in hypo-cit compared with $36 \pm 5 \mathrm{mEq} /$ day in normo- and $39 \pm 7 \mathrm{mEq} /$ day in low-cit, $P<0.05$ and $<0.025$ respectively, none of the parameters was different between subgroups. When comparing the combined low-/hypo-cit group ( $\mathrm{U}_{\mathrm{Cit}} \times \mathrm{V}<2.12 \mathrm{mmol} / \mathrm{day}, n=11$ ) with normo-cit, however, dietary fibre intake was lower in the former ones $(11.9 \pm 1.6 \mathrm{~g} /$ day versus $18.3 \pm 1.8$, $P=0.037)$, and so was $\mathrm{U}_{\mathrm{Ca}_{\mathrm{a}}} \times \mathrm{V}(6.51 \pm 0.84 \mathrm{mmol} / \mathrm{day}$ versus $9.41 \pm 0.81, P=0.029$ ).

Table 2 summarizes important correlations between $\mathrm{U}_{\mathrm{Ci}} \times \mathrm{V}$ and various other parameters. Positive correlations between $U_{C i t} \times V$ and $S_{c r e a}, C_{c r e a}, U_{C a} \times V$, $\mathrm{U}_{\mathrm{Mg}} \times \mathrm{V}$ and GI-alkali as well urine volume and dietary fibre intake were noted. Among the 107 male controls, citrate excretion was also positively, though less strongly, correlated with urine volume $(r=0.240, P=$ $0.014)$. Figure 1 demonstrates that fibre consumption below $10 \mathrm{~g} /$ day was always associated with low- or hypo-cit, whereas RCSF whose fibre consumption was $>22.5 \mathrm{~g} / \mathrm{d}$ all were normocitraturic. In RCSF whose fibre consumption was between 10 and $22.5 \mathrm{~g} / \mathrm{day}$, an

Table 2. Simple linear correlations between $\mathrm{U}_{\mathrm{Ct}} \times \mathrm{V}$ and other parameters in all $34 \mathrm{RCSF}$

\begin{tabular}{|c|c|c|c|c|}
\hline$y$ axis & $x$ axis & $r$ value & slope & $P$ \\
\hline $\mathrm{U}_{\mathrm{at}_{1}} \times \mathrm{V}$ & $\begin{array}{l}\text { S-Crea } \\
C_{\text {crea }} \\
\text { Volume } \\
U_{\mathrm{C}_{\mathbf{b}}} \times \mathrm{V} \\
\mathrm{U}_{\mathbf{M}_{\mathbf{E}}} \times \mathrm{V} \\
\mathrm{U}_{\mathbf{K}} \times \mathrm{V} \\
\text { GI-alkali } \\
\text { Fibre intake }\end{array}$ & $\begin{array}{l}0.490 \\
0.440 \\
0.440 \\
0.570 \\
0.370 \\
0.280 \\
0.470 \\
0.460\end{array}$ & $\begin{array}{l}-0.04 \\
0.02 \\
0.0001 \\
0.15 \\
0.24 \\
0.01 \\
0.02 \\
0.02\end{array}$ & $\begin{array}{l}0.003 \\
0.010 \\
0.009 \\
0.0004 \\
0.032 \\
0.111, \mathrm{NS} \\
0.006 \\
0.009\end{array}$ \\
\hline
\end{tabular}

S-Crea, fasting serum creatinine before $\mathrm{NH}_{4} \mathrm{Cl}$ loading. $\mathrm{NS}$, not significant.

Table 1. Twenty-four-hour urine data (mean \pm SEM) from 34 RCSF.

\begin{tabular}{|c|c|c|c|}
\hline Measurement & $\begin{array}{l}\text { Normo-cit } \\
(n=23)\end{array}$ & $\begin{array}{l}\text { Low-cit } \\
(n=6)\end{array}$ & $\begin{array}{l}\text { Hypo-cit } \\
(n=5)\end{array}$ \\
\hline 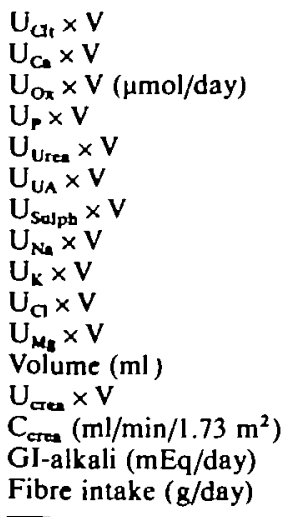 & $\begin{array}{c}3.07 \pm 0.15 \\
9.41 \pm 0.81 \\
334 \pm 27 \\
32.9 \pm 1.7 \\
415 \pm 16 \\
3.60 \pm 0.15 \\
21.9 \pm 1.3 \\
233 \pm 17 \\
63 \pm 4 \\
229 \pm 17 \\
4.64 \pm 0.34 \\
2051 \pm 158 \\
15.5 \pm 0.5 \\
109.7 \pm 4.4 \\
36 \pm 5 \\
18.3 \pm 1.8\end{array}$ & $\begin{array}{c}1.94 \pm 0.05^{* *} \\
6.67 \pm 0.8 \\
358 \pm 17 \\
31.7 \pm 2.8 \\
397 \pm 17 \\
3.40 \pm 0.22 \\
21.3 \pm 1.0 \\
193 \pm 14 \\
73 \pm 7 \\
191 \pm 14 \\
3.77 \pm 0.42 \\
1654 \pm 214 \\
15.1 \pm 0.9 \\
103.6 \pm 8.0 \\
39 \pm 7 \\
12.6 \pm 2.5\end{array}$ & $\begin{array}{c}1.18 \pm 0.23^{\circ 0} \\
6.31 \pm 1.65 \\
310 \pm 80 \\
33.1 \pm 8.0 \\
387 \pm 45 \\
3.50 \pm 0.59 \\
21.7 \pm 2.3 \\
177 \pm 41 \\
55 \pm 10 \\
178 \pm 41 \\
3.67 \pm 0.61 \\
1399 \pm 332 \\
15.3 \pm 1.7 \\
114.4 \pm 17.2 \\
14 \pm 4^{\circ} \\
11.0 \pm 2.0\end{array}$ \\
\hline
\end{tabular}

All values except $U_{0 x} \times V(\mu \mathrm{mol} /$ day), volume $(\mathrm{ml})$, Gl-alkali $(\mathrm{mEq} / \mathrm{day})$ and fibre intake (g/day) are mmol/day. For abbreviations, see 'Methods'. Cit, urinary citrate excretion rate; Hypo-cit, $<1.70 \mathrm{mmol} / \mathrm{day} ;$ Low-cit, $1.70-2.11 \mathrm{mmol} / \mathrm{day}$. ${ }^{+} P<0.05$ versus Normo-cit; ${ }^{\circ} P<0.025$ versus Low-cit; ${ }^{\circ 2} P<0.01$ versus low-cit; ${ }^{* *} P<0.001$ versus normo-cit. In the combined low-/hypo-cit group, fibre intake was lower than in normo-cit $(11.9 \pm 1.6$ versus $18.3 \pm 1.8 \mathrm{~g} / \mathrm{day}, P=0.037)$. 


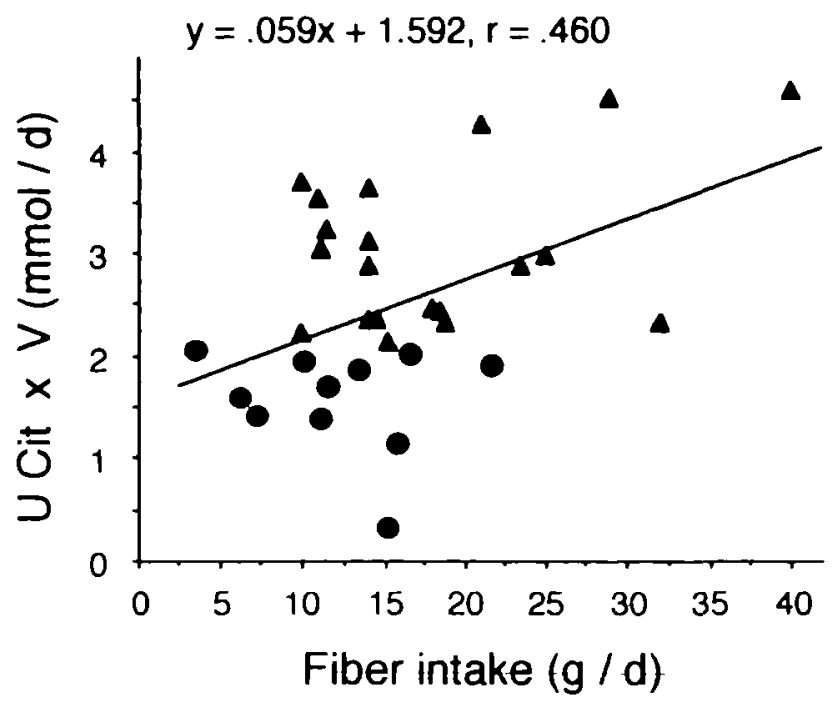

Fig. 1. 24-h urinary citrate excretion rate ( $y$ axis) in relation to daily intake of vegetable fibres calculated from dietary protocols ( $x$ axis). Circles, RCSF with UCit $\times \mathrm{V}<2.12 \mathrm{mmol} /$ day $(<400 \mathrm{mg} /$ day $)(n=$ $11)$; triangles, RCSF with normocitraturia ( $n=20$; three RCSF missing due to inappropriately returned dietary protocols).

abnormality of urine acidification (see paragraph on $\mathrm{NH}_{4} \mathrm{Cl}$ loading) occurred in six of seven with low/hypo-cit, but only in three of 14 with normo-cit $(P=0.034$, Chi-square $)$. There was only a trend for a positive correlation between urinary excretion rates of citrate and potassium, whereas no correlations were found between $\mathrm{U}_{\mathrm{Cit}} \times \mathrm{V}$ and urinary markers of protein intake (Urea, UA, Sulph) as well as of sodium consumption $(r=0.280, P=0.105)$.

In a multiple regression analysis, $\mathrm{U}_{\mathrm{Cit}} \times \mathrm{V}$ in $\mathrm{RCSF}$ was positively correlated $(r=0.700, P=0.004)$ with a combination of the four factors $C_{\text {crea }}$ (partial $F=2.9$ ), urine volume (partial $F=0.1$ ), GI-alkali (partial $F=$ 3.2) and dietary fibre consumption (partial $F=6.5$ ). When correlating urinary citrate with only GI-alkali and dietary fibres combined, a positive correlation was again noted $(r=0.600, P=0.002)$; partial $F$ values were 6.5 for Gl-alkali and 6.0 for dietary fibre intake respectively.

Since $U_{C i t} \times V$ was positively correlated with $U_{C a} \times V$, RCSF were divided into hypercalciurics (HCSF, $\mathrm{U}_{\mathrm{C}_{\mathrm{a}}} \times \mathrm{V}>9.00 \mathrm{mmol} / \mathrm{day}, n=12$ ) and normocalciurics (NCSF, $n=22$ ). Table 3 summarizes values of $24-h$ urine excretion rates, $\mathrm{C}_{\text {crea }}$, GI-alkali and daily fibre intake in HCSF and NCSF. $U_{\mathrm{Cit}} \times \mathrm{V}$ was higher in HCSF than in NCSF; low-cit, however, occurred in two of $12 \mathrm{HCSF}$ and nine of $22 \mathrm{NCSF}(P=0.289$, Chisquare), and hypo-cit was found in one of $12 \mathrm{HCSF}$ and four of $22 \mathrm{NCSF}(P=0.788$, Chi-square). Also elevated in HCSF versus NCSF were excretion rates of $\mathrm{Ox}, \mathrm{P}$, urea, Sulph, $\mathrm{Mg}$, urinary volume, $\mathrm{C}_{\text {crea }}$ and daily fibre consumption. Since values of $\mathrm{C}_{\text {crea }}$ were higher among HCSF, urinary parameters were also expressed relative to creatinine ( $\mathrm{mmol} / \mathrm{mmol}$ ratios); after this calculation, significant differences between $\mathrm{HCSF}$ and NCSF remained for $\mathrm{Ca} / \mathrm{Crea}, \mathrm{P} / \mathrm{Crea}$, and
Tabłe 3. Differences between hypercalciuric (HCSF) and normocalciuric (NCSF) recurrent calcium stone formers

\begin{tabular}{|c|c|c|c|}
\hline Measurement & $\operatorname{HCSF}(12)$ & NCSF (22) & $P$ \\
\hline 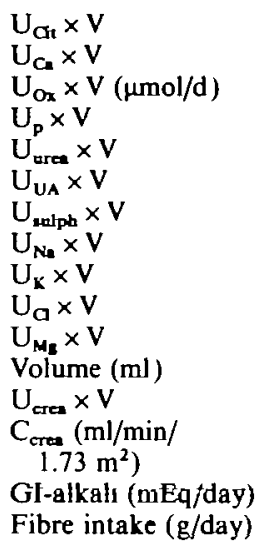 & $\begin{array}{c}3.19 \pm 0.29 \\
13.00 \pm 0.50 \\
394 \pm 40 \\
38.4 \pm 2.8 \\
447 \pm 21 \\
3.73 \pm 0.17 \\
24.1 \pm 1.6 \\
255 \pm 27 \\
67 \pm 5 \\
249 \pm 28 \\
5.75 \pm 0.40 \\
2232 \pm 178 \\
16.4 \pm 0.8 \\
120.3 \pm 7.6 \\
42.4 \pm 7.0 \\
20.2 \pm 2.8\end{array}$ & $\begin{array}{c}2.27 \pm 0.17 \\
6.00 \pm 0.35 \\
303 \pm 23 \\
29.5 \pm 1.7 \\
386 \pm 14 \\
3.45 \pm 0.18 \\
20.5 \pm 1.0 \\
197 \pm 14 \\
62 \pm 4 \\
196 \pm 13 \\
3.63 \pm 0.22 \\
1696 \pm 161 \\
14.9 \pm 0.5 \\
103.4 \pm 4.2 \\
28.7 \pm 3.9 \\
13.9 \pm 1.4\end{array}$ & $\begin{array}{l}0.014 \\
0.0001 \\
0.046 \\
0.011 \\
0.028 \\
0.313, \mathrm{NS} \\
0.020 \\
0.052, \mathrm{NS} \\
0.576, \mathrm{NS} \\
0.105, \mathrm{NS} \\
0.0003 \\
0.019 \\
0.171, \mathrm{NS} \\
\\
0.040 \\
0.109, \mathrm{NS} \\
0.035\end{array}$ \\
\hline
\end{tabular}

All values are means \pm SEM; $P$ values are for differences between HCSF and NCSF (Mann-Whitney $U$ test). For abbreviations, see 'Methods' and Table 1.

$\mathrm{Mg} / \mathrm{Crea}$, whereas they disappeared for Cit/Crea $(P=0.066)$, Ox/Crea, Urea/Crea, and Sulph/Crea. A positive correlation was also noted between daily fibre intake and $\mathrm{U}_{\mathrm{C}} \times \mathrm{V}(r=0.440, P=0.014)$.

\section{Fasting blood and urine samples before/after $\mathrm{NH}_{4} \mathrm{Cl}$ loading}

Table 4 summarizes the most important fasting blood and 2-h urine acid-base parameters in controls as well as in RCSF with normo-cit, low-cit and hypo-cit before and after $\mathrm{NH}_{4} \mathrm{Cl}$. Among stone formers with low-cit and hypo-cit, serum anion gap was higher than in controls and RCSF with normo-cit, both before and after $\mathrm{NH}_{4} \mathrm{Cl}$ loading. During $\mathrm{NH}_{4} \mathrm{Cl}$ loading there was a trend for venous bicarbonate concentration to slightly decrease in the four groups, limit of significance

Tabłe 4. Fasting acid-base parameters and urinary cıt/crea ratios (means \pm SEM) before and after $\mathrm{NH}_{4} \mathrm{Cl}$ loading in 14 healthy male controls and 34 RCSF

\begin{tabular}{|c|c|c|c|c|}
\hline Measurement & $\begin{array}{l}\text { Controls } \\
(n=14)\end{array}$ & $\begin{array}{l}\text { ormo-cit } \\
z=23 \text { ) }\end{array}$ & $\begin{array}{l}\text { ow-cit } \\
n=6 \text { ) }\end{array}$ & $\begin{array}{l}\text { Hypo-cit } \\
(n=5)\end{array}$ \\
\hline $\begin{array}{l}\mathrm{AG}_{0}(\mathrm{mM}) \\
\mathrm{AG}_{3}(\mathrm{mM}) \\
\mathrm{Bic}_{.}(\mathrm{mM}) \\
\text { Bic..3 }_{3}(\mathrm{mM}) \\
\text { Urine } \mathrm{pH}_{0} \\
\text { Urine } \mathrm{pH}_{3} \\
\mathrm{AG} / \mathrm{Crea}_{0} \\
\mathrm{AG} / \mathrm{Crea}_{3} \\
\mathrm{Cit} / \mathrm{Crea}_{0} \\
\mathrm{Cit} / \mathrm{Crea}_{3}\end{array}$ & $\begin{array}{l}10.3 \pm 0.7 \\
10.2 \pm 10 \\
25.9 \pm 0.7 \\
24.8 \pm 0.5 \\
\frac{5.93 \pm 0.23}{4.94 \pm 0.05} \\
\frac{3.34 \pm 0.80}{0.32 \pm 0.43} \\
0.18 \pm 0.02 \\
0.10 \pm 0.02\end{array}$ & $\begin{array}{l}12.2 \pm 0.8 \\
11.8 \pm 0.8 \\
24.9 \pm 0.5 \\
23.8 \pm 0.6 \\
6.07 \pm 0.16 \\
5.08 \pm 0.04 \dagger \\
3.53 \pm 0.41 \\
0.02 \pm 0.31 \\
0.19 \pm 0.02 \\
0.10 \pm 0.01\end{array}$ & $\begin{array}{l}13.4 \pm 0.7 \dagger \\
17.3 \pm 2.3 \dagger \\
26.7 \pm 0.7 \\
19.7 \pm 2.0 \dagger \\
6.26 \pm 0.18 \\
5.27 \pm 0.07^{*} \\
4.66 \pm 0.95 \\
1.05 \pm 0.48 \\
0.10 \pm 0.01 \dagger \\
0.04 \pm 0.01 \dagger\end{array}$ & $\begin{array}{l}16.8 \pm 1.4^{* *} \\
16.7 \pm 0.6^{*} \\
24.8 \pm 1.4 \\
\frac{21.8 \pm 1.0}{5.78 \pm 0.16} \\
\frac{5.28 \pm 0.10 \dagger}{3.21 \pm 0.88} \\
1.26 \pm 0.38 \\
0.11 \pm 0.04 \\
0.04 \pm 0.01^{\circ}\end{array}$ \\
\hline
\end{tabular}

AG, serum anion gap; bic., venous bicarbonate. ' $P<0.05$; $+P<0.025 ; * P<0.01 ; * \quad P<0.005$ versus healthy controls. Underlined values were significantly different from corresponding values before $\mathrm{NH}_{4} \mathrm{Cl}$ loading $(P<0.05$, Wilcoxon signed-rank test). 
being reached in controls and in RCSF with low-cit or hypo-cit. Urine $\mathrm{pH}$ was not significantly different between subgroups on day 0 ; it uniformly fell upon acid loading, but less markedly in RCSF than in controls. Urine anion gap/creatinine ratios also were similar between subgroups on day 0 ; after $\mathrm{NH}_{4} \mathrm{Cl}$ they fell sharply in all subgroups, as did urine Cit/Crea ratios. The latter ones were abnormally low in RCSF with low-cit or hypo-cit, i.e. they had 'fasting hypocitraturia'.

Figure 2 is a scatter plot of fasting venous bicarbonate concentrations versus urine $\mathrm{pH}$ values after $\mathrm{NH}_{4} \mathrm{Cl}$ loading; the shaded area is a nomogram obtained in 23 healthy volunteers. Urine $\mathrm{pH}$ decreased below 5.32 and venous bicarbonate remained above $20.5 \mathrm{mmol} / \mathrm{l}$ in all the normal subjects. However, 18 of the 34 RCSF that we studied fell out of the nomogram: two normocitraturics, with urine $\mathrm{pH}$ values of 4.84 and 5.03 in the face of blood bicarbonate concentrations of about $28 \mathrm{mM}$, were considered to be normal. In one RCSF with low-cit, venous bicarbonate after $\mathrm{NH}_{4} \mathrm{Cl}$ loading was inadvertently not determined; however, since his urine $\mathrm{pH}$ decreased from 6.67 to 5.49 after acid loading while his serum chloride concentration rose from 104 to $106 \mathrm{mmol} / \mathrm{l}$, he was considered abnormal, but not depicted in Figure 2. Thus, 16 of 34 RCSF (47.1\%) had an abnormality in urine acidification, characterized either as insufficiently acidic urines in the presence of normal venous bicarbonate concentrations, or as sufficiently acidic urines at the expense of systemic acidosis (venous bicarbonate concentration $<$ $20.5 \mathrm{mmol} / \mathrm{l}$ ), or both. Abnormal urine acidification occurred in 10 of 11 RCSF with low-/hypo-cit, but only in six 23 with normo-cit $(P=0.0004$, Chi-square); $\mathrm{U}_{\mathrm{Cit}} \times \mathrm{V}$ tended to be inversely correlated with fasting urine $\mathrm{pH}$ after $\mathrm{NH}_{4} \mathrm{Cl}$ loading $(r=-0.300, P=0.064)$. The prevalence of abnormal urinary acidification was similar amongst HCSF ( 7 of 12) and NCSF ( 9 of 22 , $P=0.331$ versus $\mathrm{HCSF}$, Chi-square).

Serum phosphate concentration was moderately

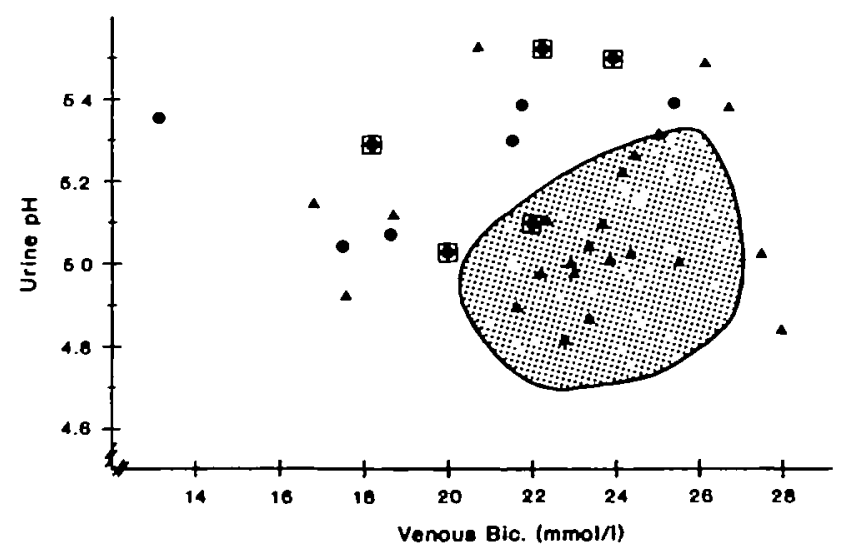

Fig. 2. Fasting urine $\mathrm{pH}$ ( $y$ axis) in relation to venous bicarbonate ( $x$ axis) after $\mathrm{NH}_{4} \mathrm{Cl}(0.1 \mathrm{mEq} / \mathrm{kg} \mathrm{BW} /$ day for 3 days) in 23 healthy men (shaded area) and 33 stone formers. Triangles, normo-cit; circles, low-cit; framed circles, hypo-cit; one RCSF with low-cit and urine $\mathrm{pH}$ of 5.49 not shown because of missing value of venous bicarbonate concentration. lower $(0.84 \pm 0.03$ versus $0.98 \pm 0.04 \mathrm{mmol} / \mathrm{l}, P<0.05)$ and serum intact PTH concentration higher $(33.0 \pm 3.2$ versus $25.0 \pm 2.1 \mathrm{pg} / \mathrm{ml}, P<0.05)$ in $\mathrm{RCSF}$ with hypocit versus controls. Only before $\mathrm{NH}_{4} \mathrm{Cl}$ loading were TmP/GFR values lower in RCSF with normo-cit $(0.76 \pm 0.03, P=0.006)$ and in those with low-cit $(0.79 \pm 0.03 \mathrm{mmol} / \mathrm{l} \mathrm{GF}, P=0.028)$ than in controls $(0.95 \pm 0.04 \mathrm{mmol} / \mathrm{GF})$. All other blood and urine parameters of calcium phosphate and bone metabolism were similar in controls and the three subgroups of RCSF, and they were not differently affected by acid loading in controls and in the various subgroups of RCSF (data not shown).

Table 5 compares parameters of calcium phosphate metabolism between healthy controls and RCSF classified either as HCSF or NCSF, before and after acid loading. Compared with controls, TmP/GFR was lower both in HCSF and NCSF, and HCSF had lower serum $\mathrm{P}$ and higher urine $\mathrm{Ca} / \mathrm{Crea}$ both before and after acid loading. In comparison with NCSF, serum calcitriol and urine $\mathrm{Ca} / \mathrm{Crea}$ were higher in $\mathrm{HCSF}$. Serum parameters and urine $\mathrm{Ca} / \mathrm{crea}$ were unaffected by acid loading, whereas TmP/GFR fell slightly in NCSF and OHP-E rose in HCSF.

\section{Frequencies of risk factors for low citraturia}

When comparing normocitraturic RCSF with the combined group of those with low-/hypo-cit, i.e. all RCSF with $U_{\mathrm{Clt}} \times \mathrm{V}<2.12 \mathrm{mmol} /$ day $(<400 \mathrm{mg} /$ day), abnormal urine acidification was significantly more frequent among the latter ones (10 of 11 versus six of 23 in normo-cit, $P=0.0004$, Chi-square). Low urine volume was found in $27.3 \%$ of RCSF with low-/hypo-cit, compared with $8.7 \%$ in those with normo-cit (NS, Chi-square); $18.2 \%$ of RCSF with low-/hypo-cit and $17.4 \%$

Table 5. Parameters of calcium phosphate and bone metabolism in fasting blood and urine samples of male controls, HCSF and NCSF before and after $\mathrm{NH}_{4} \mathrm{Cl}$ loading

\begin{tabular}{|c|c|c|c|c|}
\hline Measurement & $\begin{array}{l}\text { Controls } \\
(n=14)\end{array}$ & $\begin{array}{l}\mathrm{HCSF} \\
(n=12)\end{array}$ & $\begin{array}{l}\text { NCSF } \\
(n=22)\end{array}$ & $P$ \\
\hline$a^{2+}(m M)$ & $1.27 \pm 0.01$ & $1.27 \pm 0.01$ & $1.26 \pm 0.01$ & NS \\
\hline $\mathrm{Ca}^{2+}{ }_{3}(\mathrm{mM})$ & $1.26 \pm 0.01$ & 1.26 & .01 & NS \\
\hline$S-P_{0}(m M)$ & $0.98 \pm 0.04$ & $0.82 \pm 0.04 \dagger$ & $0.88 \pm 0.03$ & NS \\
\hline $\mathrm{S}-\mathrm{P}_{3}(\mathrm{mM})$ & $0.95 \pm 0.05$ & $0.77 \pm 0.04 \dagger$ & $0.86 \pm 0.03$ & NS \\
\hline I-PTH ${ }_{0}(p g /$ & $25.0 \pm 2.1$ & $27.2 \pm 3.3$ & $27.8 \pm 2.0$ & NS \\
\hline I-PTH ${ }_{3} \mathrm{ml}$ ) & $28.7 \pm 3.1$ & 26.5 & 30.5 & NS \\
\hline $1,25-\mathrm{D} 3_{0}(\mathrm{pg} /$ & $50.5 \pm 5.1$ & $65.3 \pm 4.5$ & $49.4 \pm 3.3$ & 0.018 \\
\hline $1,25-\mathrm{D} 3, \mathrm{ml})$ & $53.8 \pm 4.9$ & $67.2 \pm 3.8^{\circ}$ & $50.4 \pm 3.5$ & 0.007 \\
\hline $\mathrm{Ca} / \mathrm{Crea}_{0}$ & $0.25 \pm 0.02$ & $0.46 \pm 0.06^{* *}$ & $0.31 \pm 0.03$ & 0.021 \\
\hline $\mathrm{Ca} / \mathrm{Crea}_{3}$ & $0.34 \pm 0.05$ & 0.5 & $0.37 \pm 0.04$ & 0.004 \\
\hline TmP/GFR & $0.95 \pm 0.04$ & $0.73 \pm 0.05^{* *}$ & $0.79 \pm 0.03+$ & NS \\
\hline $\left.\mathrm{TmP} / \mathrm{GFR}_{3} \mid \mathrm{GF}\right)$ & $0.84 \pm 0.05$ & $0.69 \pm 0.04^{\circ}$ & $0.73 \pm 0.02$ & NS \\
\hline OHP-E E $_{0}(\mu \mathrm{mol} /$ & $1.10 \pm 0.13$ & $1.66 \pm 0.29$ & $\overline{1.67 \pm 0.13^{*}}$ & NS \\
\hline OHP-E $E_{3}$ GF) & $1.44 \pm 0.30$ & $2.28 \pm 0.50$ & $1.59 \pm 0.27$ & NS \\
\hline
\end{tabular}

I-PTH, intact PTH; 1,25-D3, calcitriol: TmP/GFR, renal phosphate threshold; OHP, hydroxyproline. Indicated $P$ values are for comparisons between HCSF and NCSF. ${ }^{\circ} P<0.05 ;^{+} P<0.025 ; * P<0.01$; ** $P<0.005$ versus healthy controls. Underlined values were significantly different from corresponding values before $\mathrm{NH}_{4} \mathrm{Cl}$ loading $(P<0.05$, Wilcoxon signed-rank test) . 
of those with normo-cit had GI-alkali below $15 \mathrm{mEq} / \mathrm{day}$; low fibre intake was present in $63.4 \%$ of RCSF with low-/hypo-cit and in $50.0 \%$ of those with normo-cit (NS, Chi-square). As shown in Figure 3, two or more risk factors for decreased citraturia occurred simultaneously in only $17.4 \%$ of RCSF with normo-cit (4 of 23 ), whereas it did so in $72.7 \%$ of RCSF with low-/hypo-cit ( 8 of $11, P=0.002$ versus normo-cit, Chi-square).

\section{Discussion}

Among the 34 recurrent calcium stone formers studied herein under free-choice diet, overt hypocitraturia ( $<1.70 \mathrm{mmol} /$ day) occurred in $15 \%$ and 'low citraturia' $(1.70-2.11 \mathrm{mmol} / \mathrm{day})$ in another $18 \%$. In the past 'idiopathic' hypocitraturia has been reported in $19-63 \%$ of patients with nephrolithiasis, either as an isolated disorder or in association with other urinary risk factors of stone formation [25]. Thus the prevalence obtained in the present study lies within the expected range inasmuch as patients with obvious causes of hypocitraturia, such as chronic diarrhoea, overt renal tubular acidosis, hypokalaemia, renal insufficiency and urinary tract infection [2] all had been carefully excluded from this study.

Four main risk factors, occurring separately or in combination, may be associated with low urinary citrate excretion and deserve further consideration: an abnormality in renal handling of acid, decreased net GI-alkali absorption, low dietary fibre consumption, and low urinary volume.

Previously, we had provided evidence for increased frequency of incomplete RTA among calcium stone formers with hypocitraturia [6]. The study, however, had been carried out under 'heavy' acid loading. In the present approach we wanted to evaluate acid-base metabolism under more 'physiological' conditions of acid loading than originally described [26]; therefore we applied only $0.05 \mathrm{~g}(0.95 \mathrm{mEq}) \mathrm{NH}_{4} \mathrm{Cl}$ per kg BW daily in three divided doses given for 3 consecutive

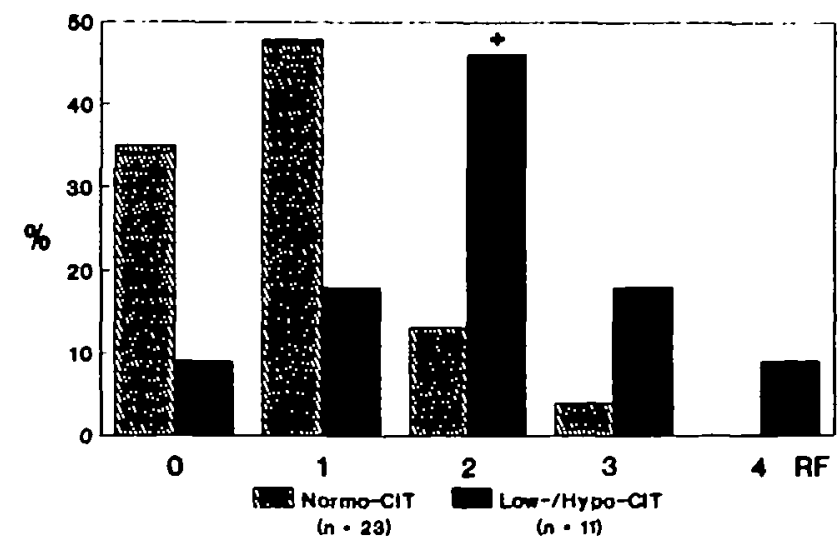

Fig. 3. Frequencies of occurrence of $0,1,2,3$, or 4 simultaneous risk factors (RF) for low citraturia $(<2.12 \mathrm{mmol} /$ day) in RCSF. + , $<0.05$ versus normo-cit (Chi-square). days. Nevertheless our healthy controls lowered their urine $\mathrm{pH}$ below 5.32, about the same level as that originally described by Wrong and Davies [26], despite 3 days of lighter acid loading. Forty-one percent of all RCSF either were unable to do so, or they only did it at the cost of metabolic acidosis. Both patterns reflect diminished and/or retarded renal excretion of acid. That the latter predisposes to hypocitraturia (in that case via intracellular acidosis) is supported by the fact that the defect in urinary acidification was significantly more frequent among RCSF with low citraturia or overt hypocitraturia (10 of 11) than among those with normocitraturia (4 of $23, P=0.0004$, Chi-square).

Our study confirms the finding by Pak [1] that urinary citrate excretion correlates with net G-I alkali absorption, when assessed indirectly from noncombustible urinary cations and anions [22]. In this study, GI-alkali absorption was particularly low in RCSF with overt hypocitraturia $(14 \pm 4 \mathrm{mEq} /$ day $)$. Since alkali intake, as estimated from dietary fibre consumption, was comparable to that observed in RCSF with low- and normo-cit, alkali absorption itself may have been reduced in RCSF with hypo-cit. Alternatively, hypocitraturia might have resulted-at least in some RCSF-from reduced intestinal absorption of citrate itself, as described by Cowley et al. [27].

Animal protein excess is often regarded as a risk factor for hypocitraturia [1,9], by virtue of the organic acid load that this type of diet conveys. In this study, however, we did not find any significant correlations between $U_{\mathrm{Cit}} \times \mathrm{V}$ and the urinary markers of protein intake, e.g. urea, uric acid, and sulphate. Reasons for that are unclear. However, it has to be noted that the studies usually referred to in the context of proteininduced hypocitraturia (quoted in [1] and [9]) actually describe increases in citraturia within the normal range of daily urinary citrate excretion after dietary restriction of protein.

We also confirm our previous finding of higher $\mathrm{U}_{\mathrm{Cit}} \times \mathrm{V}$ in HCSF, compared with NCSF [28]. This seems to be partially related to higher $\mathrm{C}_{\text {crea }}$ values in HCSF. There is, however, another potential explanation for the finding: urinary excretion rate of citrate was positively correlated with urinary excretion rates of calcium, as previously demonstrated by others $[7,29]$, as well as with that of magnesium. Citrate forms soluble complexes with both ions, and such complexes cannot be absorbed along the nephron [13]: thus the higher the filtered load of calcium or magnesium, the higher the urinary output of citrate.

Two original observations are provided by the present study. First, dietary intake of vegetable fibres is reduced in RCSF with low-/hypo-cit, and a positive correlation exists between urinary citrate excretion and fibre intake. The prevalence of calcium nephrolithiasis is known to be inversely related to dietary fibre intake [30], and stone formers have been reported to ingest less fibres than the normal population [31]. Until now, however, the mechanism governing this association had remained unknown, an intestinal hyperabsorption of calcium consecutive to insufficient binding of the 
ion due to missing fibres with subsequent hypercalciuria being the most widely postulated mechanism [30]. If such was the case, HCSF ought to have lower fibre intake than NCSF. The opposite, however, was observed in this study: fibre consumption was higher in HCSF, and urinary calcium and fibre consumption were positively, not negatively correlated. Therefore, the intestinal hyperabsorption of calcium that we must postulate in HCSF was not the consequence of missing fibres, but most probably of increased calcitriol levels, as generally accepted (reviewed in [32]) and observed also in the present study. Since dietary fibres emerge as a source of alkali [20], our finding rather suggests that increased fibre ingestion protects against calcium renal stone disease by raising urinary citrate excretion.

The other contribution of this study is the demonstration that a positive correlation exists between urinary citrate and urinary volume. The mechanism behind this association remains speculative but might involve the impact of the proximal luminal flow rate on bicarbonate reabsorption. Indeed, net bicarbonate reabsorption positively correlates with luminal flow rate along the proximal tubule [33-35], due to flowdependent stimulation of proton secretion by proximal tubular cells [35]. Thus at higher flow rates, cytosolic pH might rise, which in turn is expected to lower citrate uptake by those cells and increase urinary citrate excretion [3].

In conclusion the present study allows to rank the most relevant causes for 'idiopathic' hypocitraturia: incomplete RTA, reduced net GI-alkali absorption, low vegetable fibre intake and low urinary volume. Whereas incomplete RTA, the most prevalent risk factor among RCSF with low citrate excretion, and reduced GI-alkali absorption had already been widely discussed in the past, low vegetable fibre intake and low urinary volume had gone unnoticed so far. Moreover in an individual stone former idiopathic hypocitraturia appears to be of multifactorial origin. Given the fact that most of these causes are readily accessible to dietary advices and medical treatment, they should be carefully looked for in recurrent idiopathic calcium stone formers.

Acknowledgements. This study was supported in part by the Swiss National Science Foundation (Grant No. 32-33543.92).

The authors thank $L$. Villiger $M D$, for his help in recruiting patients for this study, and greatly acknowledge the assistance of $\mathrm{K}$. Lippuner $M D$, and the technicians from the Calcium Phosphate Laboratory of the Policlinic of Medicine.

\section{References}

1. Pak CYC. Citrate and renal calculi: new insights and future directions. Am J Kidney Dis 1991; 17: 420-425

2. Hosking DH, Wilson JWL, Liedtke RR, Smith LH, Wilson DM. Urinary citrate excretion in normal persons and patients with idiopathic calcium urolithiasis. J Lab Clin Med 1985; 106: 682-689

3. Simpson DP. Citrate excretion: a window on renal metabolism. Am J Physiol 1983; 244 (Renal Fluid Electrolyte Physiol 13): F223-F234

4. Ostberg $O$. Studien aber die Zitronensăurenausscheidung der
Menschenniere in normalen und pathologischen Zustănden. Scand Arch Physiol 1931; 62: 81-222

5. Clarke E, Evans BM, MacIntyre I, Milne MD. Acidosis in experimental electrolyte depletion. Clin Sci 1955; 14: 421-440

6. Jaeger Ph, Portmann L, Jacquet AF, Burckhardt P. Study of the mechanisms of hypocitraturia in idiopathic stone formers. In: Martelli A, Buli P, Marchesini B, eds. Inhibitors of Crystallization in Renal Lithiasis and their Clinical Application. Acta Medica, Bologna 1988: 183-186

7. Nicar MJ, Skurla C, Sakhaee K, Pak CYC. Low urinary citrate excretion in nephrolithiasis. Urology 1983; $21: 8-14$

8. Kok DJ, Iestra JA, Doorenbos CJ, Papapoulos SE. The effects of dietary excesses in animal protein and in sodium on the composition and the crystallization kinetics of calcium oxalate monohydrate in urines of healthy men. $J$ Clin Endocrinol Metab 1990; 71: 861-867

9. Goldfarb S. Dietary factors in the pathogenesis and prophylaxis of calcium nephrolithiasis. Kidney Int 1988; 34: 544-555

10. Fourman P, Robinson JR. Diminished urinary excretion of citrate during deficiencies of potassium in man. Lancet 1953; 2: $656-657$

11. Levi M, McDonald LA, Preisig PA, Alpern RJ. Chronic K depletion stimulates rat renal brush-border membrane Na-citrate cotransporter. Am J Physiol 1991; 261 (Renal Fluid Electrolyte Physiol 30): F767-F773

12. Hess B, Casez J-P, Takkinen R, Ackermann D, Jaeger Ph. Relative hypoparathyroidism and calcitriol up-regulation in hypercalciunc calcium renal stone formers-impact of nutrition. Am J Nephrol 1993; 13: 18-26

13. Rudman D, Dedonis JL, Fountain MT et al. Hypocitraturia in patients with gastrointestinal malabsorption. $N$ Engl J Med 1980; 303: 657-661

14. Conway MA, Mattland ATK, Rennie JB. The urinary citrate excretion in patients with renal calculi. $B r J$ Urol 1949; 21:30-38

15. Hodgkinson $A$. Citric acid excretion in normal adults and in patients with renal calculus. Clin Sci 1962; 23: 203-212

16. Robertson WG, Peacock M, Heybum PJ, Hanes FA. Epidemiological risk factors in calcium stone disease. Scand J Urol Nephrol 1980; [Suppl 53]: 15-30

17. Toftegaard Nielsen T. A method for enzymatic determination of citrate in serum and urine. Scand J Clin Lab Invest 1976; 36: 513-519

18. Chiriboga J. Some properties of an oxalic oxidase purified from barley seedlings. Biochem Biophys Res Commun 1963; 11: 277-282

19. Bucholz AE, Verplough CI, Smith JL. A method for the simultaneous measurement of chloride, nitrate, and sulfate in aqueous samples by nonsuppressed ion chromatography. $J$ Chrom Science 1982; 20: 449-50I

20. Souci SW, Fachmann W, Kraut H. Food Composition and Nutrition Tables 1986/87 (ed. 3). Wissenschaftliche Verlagsgesellschaft mbH, Stuttgart: 1986

21. Rudman D. Nutrition. In: Braunwald E. et al., eds. Harrison's Principles of Internal Medicine (ed. 11), chap 4. Mc Graw-Hill Book Company, New York, NY,: 1987: 389

22. Oh MS. A new method for estimating G-I absorption of alkali. Kidney Int 1989; 36: 915-917

23. Battle DC, Hizon M, Cohen E, Guttermann C, Gupta R. The use of the urinary anion gap in the diagnosis of hyperchloremic metabolic acidosis. $N$ Engl J Med 1988; 318: 594-599

24. Walton RJ, Bijvoet OLM. Nomogram for derivation of renal threshold phosphate concentration. Lancet 1975; 2: 309-310

25. Pak CYC. Citrate and renal calculi. Miner Electrolyte Metab 1987; 13: 257-266

26. Wrong $O$, Davies HEF. The excretion of acid in renal disease. $Q J$ Med 1959; 28: 259-313

27. Cowley DM, McWhinney BC, Brown JM. Chemical factors important to calcium nephrolithiasis: evidence for impaired hydroxycarboxylic acid absorption causing hyperoxaluria. Clin Chem 1987; 33: 243-247

28. Jaeger Ph, Portmann L, Jacquet AF, Burckhardt P. Indications au dosage du citrate urinaire dans le bilan d'une lithiase rénale idiopathique. Schweiz Med Wochenschr 1986; 116: 371-373 
29. Welsham SG, McGeown MG. Urinary citrate excretion in stoneformers and normal controls. Br $J$ Urol 1976; 48: 7-11

30. Robertson WG. Diet and calcium stones. Miner Electrolyte Metab 1987; 13: 228-234

31. Griffith HM, O'Shea B, Kevany JP, McCormick JS. A control study of dietary factors in renal stone formation. Br J Urol 1981; 53: 416-420

32. Hess $\mathrm{B}$, Jaeger $\mathrm{Ph}$. The tale of parathyroid function in idiopathic hypercalciuria. Scanning Microsc 1993; 7: 403-408
33. Alpern RJ, Cogan MG, Rector FC Jr. Flow dependence of proximal tubular bicarbonate absorption. Am J Physiol 1983; 245 (Renal Fluid Electrolyte Physiol 14): F478-484

34. Pitts RF, Lotspeich WD. Bicarbonate and the renal regulation of acid-base balance. Am J Physiol 1982; 236 (Renal Fhid Electrolyte Physiol 5): F163-F174

35. Cogan MG, Maddox DA, Lucci MS, Rector FC Jr. Control of proximal bicarbonate reabsorption in normal and acidotic rats. J Clin Invest 1979; 64: 1168-1180

Received for publication 8.7.93

Accepted in revised form 9.11 .93 